\title{
Inhibition of phosphodiesterase 5 restores endothelial function in renovascular hypertension
}

\author{
Ananda T Dias ${ }^{1}$, Amanda S Cintra ${ }^{2}$, Jéssica C Frossard ${ }^{2}$, Zaira Palomino ${ }^{3}$, Dulce E Casarini ${ }^{3}$, Isabele BS Gomes ${ }^{4}$, \\ Camille M Balarini ${ }^{5}$, Agata L Gava', Bianca P Campagnaro ${ }^{6}$, Thiago MC Pereira ${ }^{6,7}$, Silvana S Meyrelles ${ }^{1}$ \\ and Elisardo C Vasquez ${ }^{1,2,6^{*}}$
}

\begin{abstract}
Background: The clipping of an artery supplying one of the two kidneys (2K1C) activates the renin-angiotensin (Ang) system (RAS), resulting in hypertension and endothelial dysfunction. Recently, we demonstrated the intrarenal beneficial effects of sildenafil on the high levels of Ang $I$ and reactive oxygen species (ROS) and on high blood pressure (BP) in 2K1C mice. Thus, in the present study, we tested the hypothesis that sildenafil improves endothelial function in hypertensive $2 \mathrm{~K} 1 \mathrm{C}$ mice by improving the NO/ROS balance.

Methods: 2K1C hypertension was induced in C57BL/6 mice. Two weeks later, they were treated with sildenafil ( $40 \mathrm{mg} / \mathrm{kg} /$ day, via oral) or vehicle for 2 weeks and compared with sham mice. At the end of the treatment, the levels of plasma and intrarenal Ang peptides were measured. Endothelial function and ROS production were assessed in mesenteric arterial bed (MAB).

Results: The 2K1C mice exhibited normal plasma levels of Ang I, II and 1-7, whereas the intrarenal Ang I and II were increased ( $\sim 35 \%$ and $\sim 140 \%$ ) compared with the Sham mice. Sildenafil normalized the intrarenal Ang I and II and increased the plasma ( 45\%) and intrarenal (+15\%) Ang 1-7. The 2K1C mice exhibited endothelial dysfunction, primarily due to increased ROS and decreased NO productions by endothelial cells, which were ameliorated by treatment with sildenafil.

Conclusion: These data suggest that the effects of sildenafil on endothelial dysfunction in $2 \mathrm{~K} 1 \mathrm{C}$ mice may be due to interaction with RAS and restoring NO/ROS balance in the endothelial cells from MAB. Thus, sildenafil is a promising candidate drug for the treatment of hypertension accompanied by endothelial dysfunction and kidney disease.
\end{abstract}

Keywords: Sildenafil, Oxidative stress, Renovascular hypertension, Angiotensin, Endothelial function, 2K1C

\section{Introduction}

High blood pressure (BP) has become a health issue, with a projected prevalence of about one third of the global population worldwide by 2025 [1], and endothelial dysfunction is the hallmark of this condition [2]. Among the different types of high BP, renovascular hypertension is an important cause of secondary hypertension, which is characterized by increased activation of the renin-angiotensin system (RAS) [3-5]. The prevalence of renovascular

\footnotetext{
* Correspondence: evasquez@pq.cnpq.br

'Laboratory of Translational Physiology, Health Sciences Center, Federal University of Espirito Santo, Vitoria, ES, Brazil

${ }^{2}$ Emescam School of Health Sciences, Vitoria, ES, Brazil

Full list of author information is available at the end of the article
}

hypertension has been estimated to be $5 \%$ of all hypertensive individuals, but it can reach higher percentage depending on the population's characteristics, e.g., renal artery stenosis can reach approximately $5 \%$ of persons aged $\geq 65$ years [6,7]. We have focused this study on this secondary hypertension because these patients are highly susceptible to develop resistance to conventional antihypertensive drugs, increasing the morbidity and mortality $[4,8]$. Thus, there is a need of studies to a better understanding and to develop new therapeutic approaches against the progression of this disease.

Experimental renovascular hypertension was introduced by Goldblatt in 1934 in dogs by performing unilateral clipping of the renal artery, referred to as the two-kidney, 
one-clip (2K1C) model. Three decades later, the rat became the main experimental model of $2 \mathrm{~K} 1 \mathrm{C}$ hypertension in our and other laboratories [9-11]. However, genetic discoveries and advances in molecular biotechnologies have provided the opportunity to develop mouse models of cardiovascular diseases, which has led to an increasing number of studies using this murine model of hypertension [12-15]. Physiologically, it is well known that unilateral renal artery stenosis reduces renal perfusion, which activates the RAS [5]. Recently, this system has been extended by the addition of a novel axis consisting of the angiotensin-converting enzyme 2 (ACE2), the heptapeptide angiotensin (Ang) 1-7, and the G protein-coupled receptor Mas [16]. ACE2 converts the vasoconstrictive and pro-oxidative peptide Ang II to Ang 1-7, which exerts vasodilatory and antioxidant effects via its receptor, Mas [16-19]. Although our laboratory analyzed some RAS peptides during the development phase of $2 \mathrm{~K} 1 \mathrm{C}$ hypertension in a murine model $[3,20,21]$, in the present study, we extended the analysis of the Ang I, II and 1-7 levels in both plasma and the stenotic kidney during the established phase of renovascular hypertension.

Endothelial dysfunction is commonly observed in chronic arterial hypertension and is characterized by impaired nitric oxide (NO) bioavailability and increased reactive oxygen species (ROS) levels. In recent years, our laboratory [15,22,23] and others [24,25] have investigated microvascular endothelial dysfunction in various models of cardiovascular disease, including the $2 \mathrm{~K} 1 \mathrm{C}$ mouse model of hypertension, which has greatly contributed to our understanding of the relationship between endogenous activation of the RAS and endothelial dysfunction in resistance arteries [15]. This model provides suitable approach to evaluate the efficacy of new drugs for the treatment of renovascular hypertension.

The phosphodiesterase 5 (PDE5) inhibitor sildenafil, which increases the vascular signaling of the NO/cGMP pathway [26,27], has successfully been used to treat erectile dysfunction and pulmonary hypertension [28], emerging as a promising alternative therapy for systemic cardiovascular dysfunctions. Our laboratory has recently shown that sildenafil was able to restore the endothelial dysfunction and blood mononuclear and liver cell DNA damage, which accompany atherosclerosis [27,29]. Moreover, Dias et al. [21] recently reported that sildenafil ameliorates the oxidative damage to the stenotic kidney and reduces the intrarenal levels of Ang II in the 2K1C mouse.

Therefore, the present study was designed to evaluate the effect of chronic treatment with sildenafil on high BP, the levels of peptide components of the RAS and vascular function in the hypertensive $2 \mathrm{~K} 1 \mathrm{C}$ mouse. We hypothesized that sildenafil reduces the deleterious effects of Ang II, increases the levels of the counterbalancing peptide
Ang 1-7 and restores the endothelial function of resistance vessels in hypertensive $2 \mathrm{~K} 1 \mathrm{C}$ mice. The confirmation of this hypothesis may provide a novel pharmacological approach to treat endothelial dysfunction and, especially, resistant hypertension.

\section{Materials and methods \\ Animals}

Experiments were performed in male wild-type mice (C57BL/6) that weighed $23 \mathrm{~g}$ on average (10-week-old). Mice were bred and maintained in the Laboratory of Translational Physiology animal facility (Vitoria, ES, Brazil) and were fed with a standard chow diet and received water ad libitum. Animals were housed in individual plastic cages with automatic controlled temperature $\left(22^{\circ} \mathrm{C}\right)$ and humidity $(60 \%)$ and were exposed to a $12 / 12 \mathrm{~h}$ light-dark cycle. All of the experimental procedures were performed in accordance with the National Institutes of Health (NIH) guidelines, and the study protocols were approved by the Institutional Animal Care and Use Committee (CEUA-EMESCAM Protocol \# 02/2013).

\section{Induction of $2 \mathrm{~K} 1 \mathrm{C}$ renovascular hypertension and treatment}

The 2K1C Ang-dependent hypertension was induced as previously described [3,12,15,21,30]. Briefly, animals were anesthetized (91/9.1 mg/kg ketamine/xylazine, i.p.). The left renal artery was exposed through a retroperitoneal flank incision and carefully isolated from the renal vein, nerves, and connective tissues. Using an ophthalmic surgical microscope (Opto Eletronica SA, model SM 2002, Belo Horizonte, MG, Brazil), a U-shaped stainless steel clip with a $0.12 \mathrm{~mm}$ wide opening was placed around the renal artery near the abdominal aorta, which decreased renal perfusion [31]. Two weeks after surgery, animals were divided into two groups (8 to 10 animals per group): renovascular hypertensive mice treated with vehicle (2K1C) and hypertensive mice treated with $40 \mathrm{mg} / \mathrm{kg} /$ day of the PDE5-inhibitor sildenafil (Viagra ${ }^{\oplus}$, Pfizer) for 2 weeks by oral gavage (2K1C-sildenafil). Shamoperated mice were used as a normotensive control group. The effectiveness of this sildenafil dose [32] was previously demonstrated in studies on endothelial dysfunction and DNA damage in our laboratory $[21,27,29]$. The outcomes were examined 28 days after induction of hypertension.

\section{Hemodynamic measurements}

Twenty six days after $2 \mathrm{~K} 1 \mathrm{C}$ procedure or sham operation, mice were anesthetized with a combination of ketamine/ xylazine $(91 / 9.1 \mathrm{mg} / \mathrm{kg}$, i.p.) and a catheter $(0.040 \mathrm{~mm}$ outer $\times 0.025 \mathrm{~mm}$ inner diameters, MicroRenathane, Braintree Science, Massachusetts, USA) was inserted into the right carotid artery for the measurement of mean arterial pressure (MAP) and heart rate (HR) recordings. The free catheter end was tunneled under the skin of the back 
to the level of the shoulder blades. Hemodynamic measurements were performed in conscious, freely moving mice in their own cages, two days after catheter placement, as already validated as a sufficient period for complete recovery from surgery by others [33] and standardized in our laboratory [3,13-15]. For the MAP and HR recordings, the arterial catheter was plugged into a disposable BP transducer (Cobe Laboratories, Colorado, USA) connected to a pressure processor amplifier and data-acquisition system (MP100, Biopac Systems, California, USA). At the beginning of the experimental session, a period of approximately $30 \mathrm{~min}$ was allowed for stabilization of cardiovascular parameters before the measurement of basal MAP and HR values in conscious mice (Acknowledge software, Biopac Systems).

\section{Assessment of endothelial function}

At the end of the treatment, animals were anesthetized using sodium pentobarbital (50 mg/kg, i.p.), and the mesenteric arterial bed (MAB) was isolated and prepared for vascular studies. The superior mesenteric artery was cannulated. Then, the MAB was transferred to a $37^{\circ} \mathrm{C}$ chamber and was perfused using a peristaltic pump (Peri-Star Pro 4-channel pump, WPI, Lu Jia Zui District, Shangai, China) at a constant flow rate $(3 \mathrm{~mL} / \mathrm{min})$ with oxygenated $\left(95 \% \mathrm{O}_{2}-5 \% \mathrm{CO}_{2}\right.$ mixture) physiological salt solution (in mmol/L: $130 \mathrm{NaCl}, 4.7 \mathrm{KCl}, 1.6 \mathrm{CaCl}_{2} \cdot 2 \mathrm{H}_{2} \mathrm{O}$, $1.18 \mathrm{KH}_{2} \mathrm{PO}_{4}, 4.7 \mathrm{MgSO}_{4} \cdot 7 \mathrm{H}_{2} \mathrm{O}, 14.9 \mathrm{NaHCO}_{3}, 0.026$ EDTA, 11.1 glucose, $\mathrm{pH}$ 7.4). The perfusion pressure was monitored using a T-tube inserted between the pump and the inflow cannula that was connected to a pressure transducer and a data acquisition system (Biopac Systems). Then, dose-response curves of acetylcholine (ACh, $3 \times$ $10^{-7}$ to $3 \times 10^{-2} \mathrm{M}$ ) and sodium nitroprusside (SNP, $3 \times$ $10^{-7}$ to $3 \times 10^{-2} \mathrm{M}$ ) were generated in the isolated MABs. The vascular responses were evaluated based on the changes in the perfusion pressure and the vasodilator responses to ACh and SNP, which were calculated as a percentage of the pre-contraction induced by norepinephrine $\left(\mathrm{NE}, 9.8 \times 10^{-6} \mathrm{M}\right)$. To assess the mechanisms underlying the vascular effect of ACh dose-response curves were generated in separate preparations containing an intact endothelium and using specific blocker agents: (a) the nonselective NO synthase (NOS) inhibitor N-nitro-L-arginine methyl ester (L-NAME, $10^{-4} \mathrm{M}$ ), (b) the nonselective inhibitor of cyclooxygenases 1 and 2 (Cox1 and Cox2) indomethacin $\left(10^{-5} \mathrm{M}\right)$ or $(\mathrm{c})$ the $\mathrm{NAD}(\mathrm{P}) \mathrm{H}$ oxidase inhibitor apocynin $(30 \mu \mathrm{M})$. The relaxation responses to $\mathrm{ACh}$ were expressed as the percentage of dilation relative to the maximal pre-contraction level. For each curve, the maximum effect $\left(R_{\max }\right)$ and the log of the concentration of the agonist that produced half of $\mathrm{R}_{\max }\left(\log \mathrm{EC}_{50}\right)$ were calculated via nonlinear regression analysis. The sensitivities of the agonists were expressed as $\mathrm{pEC}_{50}\left(-\log \mathrm{EC}_{50}\right)$. The difference in the area under the curve ( $\triangle$ AUC) for each of the responses of the MAB to $\mathrm{ACh}$ in the presence of each inhibitor were calculated, and these results were expressed in arbitrary units (a.u.).

\section{Measurements of the angiotensin peptide levels}

The plasma and intrarenal levels of Ang I, II and 1-7 were analyzed via high performance liquid chromatography (HPLC), as previously reported $[20,21,30]$. For this analysis, blood was collected in the presence of EDTA and a protease inhibitor cocktail (Product \# P2714, SigmaAldrich), and after centrifugation (9.5 $g$, for $20 \mathrm{~min}$ ) using a refrigerated centrifuge $\left(4^{\circ} \mathrm{C}\right)$, plasma was collected for further analysis. The Ang peptides were extracted using Oasis C18 columns previously activated with methanol $(5 \mathrm{~mL})$, tetrahydrofuran $(5 \mathrm{~mL})$, hexane $(5 \mathrm{~mL})$ and water $(10 \mathrm{~mL})$. After activation, the samples were eluted in ethanol/acetic acid/water at proportions $90 \%-4 \%-6 \%$. The eluates were dried, re-dissolved in $500 \mu \mathrm{L}$ of mobile phase A (5\% acetonitrile in $0.1 \%$ phosphoric acid) and filtered for analysis by HPLC. The Ang peptides in each sample were separated using a reverse-phase ODS Aquapore 300 $(250 \times 4.6 \mathrm{~mm}) \mathrm{HPLC}$ column with a particle size of $7 \mu \mathrm{m}$ (Perkin-Elmer's Brownlee Columns, Norwalk, USA) using a 5-35\% gradient of mobile phase B: $95 \%$ acetonitrile in $0.1 \%$ phosphoric acid at a flow of $1.5 \mathrm{~mL} / \mathrm{min}$ for $40 \mathrm{~min}$. The Ang peptides were identified by comparing them with the retention times and peak heights of standard peptides.

For renal analysis of the Ang peptides, they were extracted from kidney homogenates and purified as performed on plasma samples. The subsequent steps, from the activation step to the HPLC analysis step using the reverse-phase column, the procedures were the same as those for plasma sample analysis. The Ang peptides were identified based on the retention time $(<6 \%)$ and peak height $(<5 \%)$ of standard Ang peptides and were normalized according to the kidney weight.

\section{Isolation and identification of endothelial cells from MAB}

At the end of the treatment, animals were anesthetized with sodium pentobarbital (50 mg/kg, i.p.), the midline of the abdomen was incised and the MAB was isolated, minced and digested with type II collagenase $(1000 \mathrm{U} / \mathrm{mL})$ at $37^{\circ} \mathrm{C}$ for $60 \mathrm{~min}$ at constant agitation. The cellular digest was filtered through a sterile 70- $\mu$ m nylon mesh to remove cell debris, centrifuged at $400 \mathrm{~g}$ for $10 \mathrm{~min}$, and washed twice in PBS. The cell pellet was resuspended in freezing solution and stored at $-80^{\circ} \mathrm{C}$ for further analysis. For flow cytometry analysis, the samples were thawed using a heated orbital shaker at $37^{\circ} \mathrm{C}$ and immediately transferred to a round-bottom tube, in which DMEM containing 20\% FBS was added in a drop wise fashion during a gentle agitation. The presence of endothelial cells in $\mathrm{MAB}$ digest was confirmed using an APC-conjugated 
monoclonal antibody against APCCAM-1 (CD31-PE). After thawed, MAB digest cell samples were resuspended at a concentration of $1 \times 10^{5}$ cells $/ \mathrm{mL}$ in PBS and incubated with $5 \mu \mathrm{L}$ of CD31-APC for $20 \mathrm{~min}$ in the dark and at room temperature. In the flow cytometry analysis, a APC-conjugated rat $\operatorname{IgG}_{2 \mathrm{a}}$ was used as an isotype-specific control to set the threshold values. From each sample, 100,000 events have been generated by a FACSCanto II flow cytometer (Becton Dickinson - BD, San Juan, CA, USA) using an appropriated filter for APC (660 nm).

\section{Measurement of endothelium ROS}

The ROS analysis was performed by flow cytometry using dihydroethidium (DHE), diaminofluorescein (DAF) and hydroxyphenyl fluorescein (HPF) to detect intracellular $\cdot \mathrm{O}_{2}{ }^{-}$, $\mathrm{NO}$ and $\cdot \mathrm{ONOO}^{-}$, respectively, as previously described [21,31]. Briefly, $160 \mathrm{mM}$ of DHE or $10 \mu \mathrm{M}$ of HPF or $2 \mu \mathrm{M}$ of DAF was added to the cell suspension $\left(10^{6}\right.$ cells) and incubated at $37^{\circ} \mathrm{C}$ for $30 \mathrm{~min}$ (DHE and HPF) or 180 min (DAF) in the dark. For positive control, samples were treated for $5 \mathrm{~min}$ with $50 \mathrm{mM} \mathrm{H}_{2} \mathrm{O}_{2}$ and/or $100 \mu \mathrm{M}$ of SNP to create oxidative stress without being toxic to the cells, whereas for negative control, the cells were incubated with ethanol. Cells were then washed, resuspended in PBS and kept on ice for immediate detection by flow cytometry (BD). For quantification of DHE, DAF and HPF fluorescence, 100,000 events were acquired and data were analyzed using the FACSDiva software (BD).

\section{Statistical analysis}

The values are expressed as the means \pm S.E.M. The Kolmogorov-Smirnov test indicated that the variables displayed a normal (Gaussian) distribution. Statistical comparisons between more than two means were performed using one-way or two-way analysis of variance (ANOVA) followed by Bonferroni's post hoc test. The statistical analyses were performed using Prism software (Prism 6, GraphPad Software, Inc., San Diego, CA, USA). A value of $\mathrm{p}<0.05$ was considered to be statistically significant.

\section{Results}

\section{Body and kidney weights}

The initial body weight was similar between the groups. By the end of the experiments, only the non-treated 2K1C group displayed reduced body weight $(-7 \%)$ compared with the Sham group $(26 \pm 0.5 \mathrm{~g})$ and the $2 \mathrm{~K} 1 \mathrm{C}$ group treated with sildenafil $(25 \pm 0.3 \mathrm{~g})$. Twenty-eight days after surgery, the left clipped kidney atrophied $(29 \pm 2.6 \mathrm{mg}, \mathrm{p}<$ $0.05)$, whereas the right non-clipped kidney displayed compensatory hypertrophy $(49 \pm 0.3 \mathrm{mg}, \mathrm{p}<0.05)$ in the non-treated 2K1C mice compared with the Sham mice (42 \pm 2.0 and $45 \pm 1.2 \mathrm{mg}$, respectively). As previously reported by our laboratory [21], sildenafil not only reduced the renal atrophy of the clipped kidney $(38 \pm 0.7 \mathrm{mg}, \mathrm{p}<$ 0.05 ) but also attenuated the compensatory hypertrophy of the contralateral kidney $(43 \pm 1.2 \mathrm{mg}, \mathrm{p}<0.05)$.

\section{Blood pressure and heart rate}

The average values of resting BP and HR measured in conscious animals 28 days after renal artery clipping are summarized in Figure 1 . As expected, the $2 \mathrm{~K} 1 \mathrm{C}$ mice exhibited a higher BP $(26 \%, \mathrm{p}<0.01)$ than the sham mice $(104 \pm 2 \mathrm{mmHg})$, and sildenafil treatment reduced these levels to values similar to those of the Sham mice (Figure 1A). The resting HR of the 2K1C mice was significantly higher $(+14 \%, \mathrm{p}<0.05)$ than that of the Sham mice (Sham: $451 \pm 18 \mathrm{bpm}$ ), but no significant difference was detected after sildenafil treatment (Figure 1B).

\section{Plasma angiotensin measurements}

Figure 2 shows the average values of the levels of the plasma (bar graphs A, C and E) and intrarenal (bar graphs B, D and F) Ang peptides 28 days after the induction of hypertension by clipping the renal artery. Analysis of the plasma levels of Ang revealed normal levels of Ang I, a

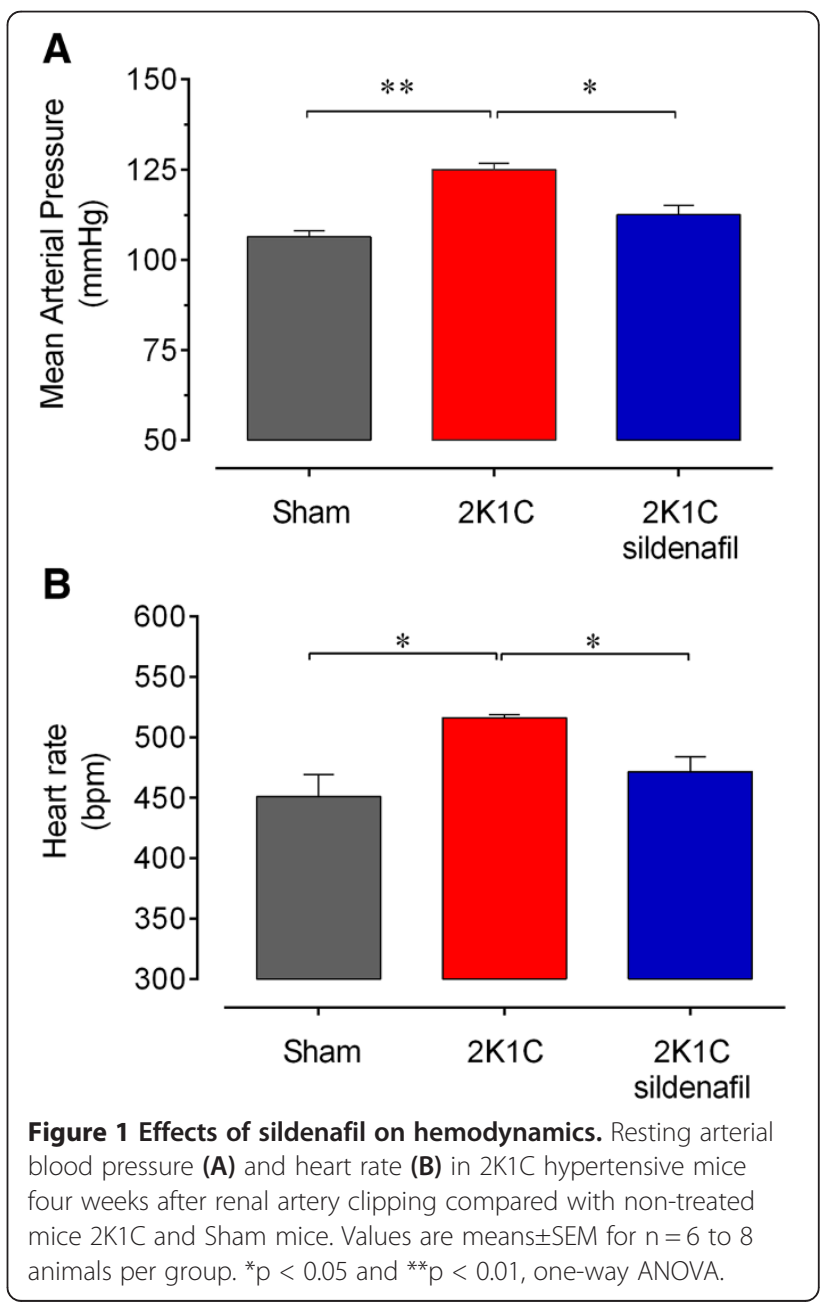



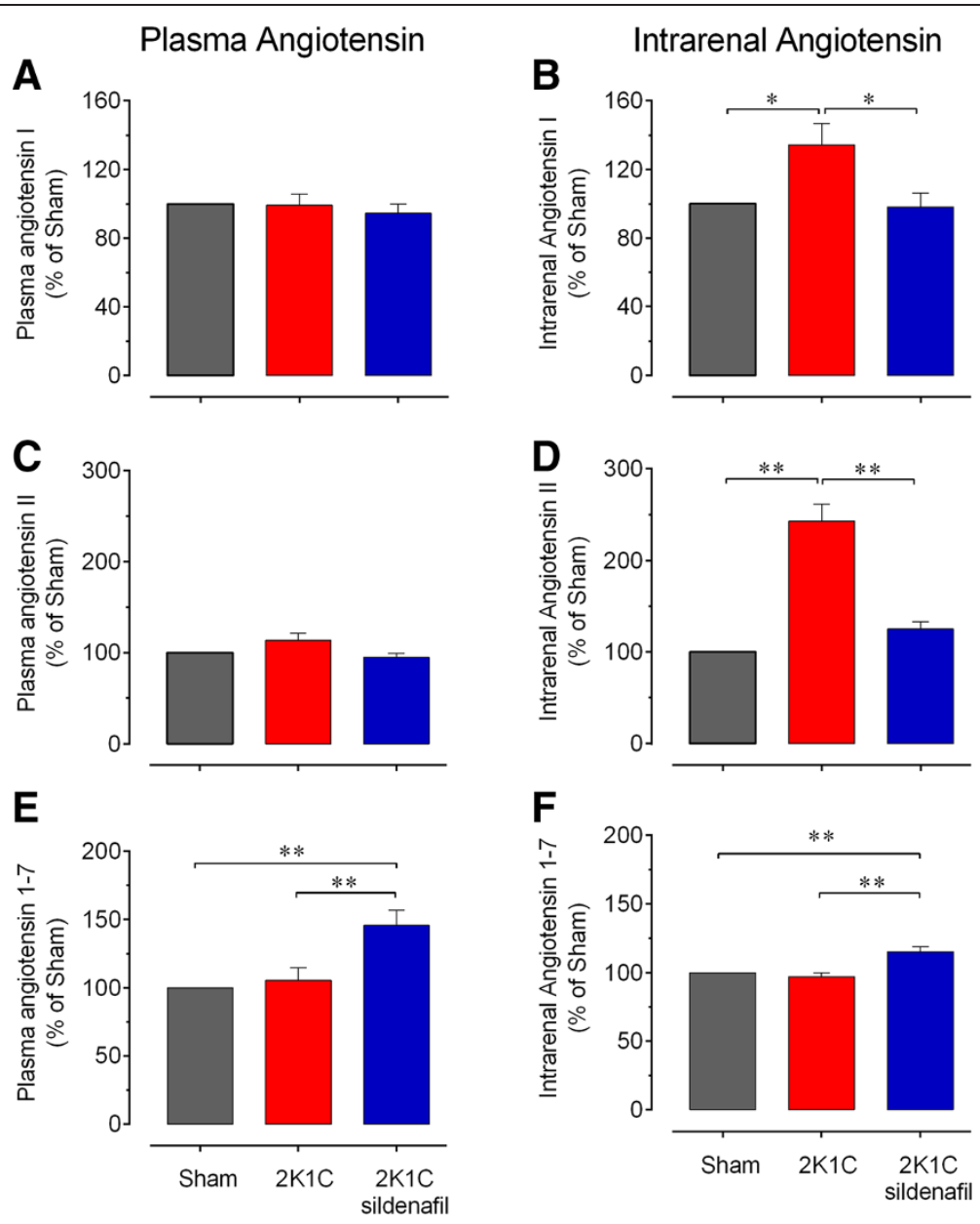

Figure 2 Effect of sildenafil on angiotensin peptides. Plasma and intrarenal levels of angiotensin I (A and B), \| (C and D) and 1-7 (E and F) in $2 \mathrm{~K} 1 \mathrm{C}$ hypertensive mice and 2K1C mice treated with sildenafil compared with the Sham group value (100\%). Values are means \pm SEM for $n=5$ to 8 animals per group. ${ }^{*} p<0.05$ and ${ }^{* *} p<0.01$, one-way ANOVA.

tendency of increased levels of Ang II $(14 \%, \mathrm{p}>0.05)$ and normal levels of Ang 1-7 in the hypertensive $2 \mathrm{~K} 1 \mathrm{C}$ mice compared to the Sham mice (Figure 2A, C and E). The 2K1C mice treated with sildenafil exhibited plasma levels of Ang I and II that were similar to those of the sham mice. However, sildenafil treatment induced a marked increase (46\%, $\mathrm{p}<0.01)$ in the plasma levels of Ang 1-7 in the hypertensive $2 \mathrm{~K} 1 \mathrm{C}$ mice (Figure $2 \mathrm{E}$ ). The intrarenal levels of Ang I were slightly higher $(34 \%, \mathrm{p}<0.05)$ and those of Ang II were markedly higher $(143 \%, \mathrm{p}<0.01)$ in the hypertensive $2 \mathrm{~K} 1 \mathrm{C}$ mice compared with the Sham mice (Figure 2B and D). However, sildenafil treatment abolished these increases in the intrarenal levels of Ang I and II (Figure 2B and $\mathrm{D}$ ) and significantly increased the normal levels of intrarenal Ang 1-7 (15\%, p < 0.01) (Figure 2F).

\section{Vascular function}

The endothelium-dependent relaxation in response to ACh at a constant flow rate in a perfused $M A B$ from each group is shown in Figure 3. The dose-response curves clearly showed a marked impairment of vascular vasodilation in response to $\mathrm{ACh}$ in the non-treated hypertensive $2 \mathrm{~K} 1 \mathrm{C}$ mice compared with the Sham mice (Figure 3A), but this difference was abolished in the $2 \mathrm{~K} 1 \mathrm{C}$ group chronically treated with sildenafil (Figure 3B). The calculation of the AUCs revealed a significant reduction in the AUC of the hypertensive $2 \mathrm{~K} 1 \mathrm{C}$ group $(40 \%, \mathrm{p}<0.01)$ compared with the sham group. Treatment with sildenafil significantly recovered the AUC to $88 \%$ of that of the sham group (Figure 3C). The maximum vascular response $\left(R_{\max }\right)$ was significantly decreased in the MABs from non-treated $2 \mathrm{~K} 1 \mathrm{C}$ mice $(-36 \%, \mathrm{p}<0.01)$ but not in those from hypertensive $2 \mathrm{~K} 1 \mathrm{C}$ mice treated with sildenafil $(-11 \%, \mathrm{p}>0.05)$, compared to those from the Sham mice (mean of $75 \pm 3 \%$, $\mathrm{p}<0.01$ ) (Figure 3D). No significant differences were detected in the $\mathrm{pEC}_{50}$ between the groups (Figure 3E). In an independent protocol, we examined the functionality of the endothelium-independent vasodilation using $\mathrm{NO}$ donor SNP. No significant differences were detected between the three groups of animals (data not shown). 

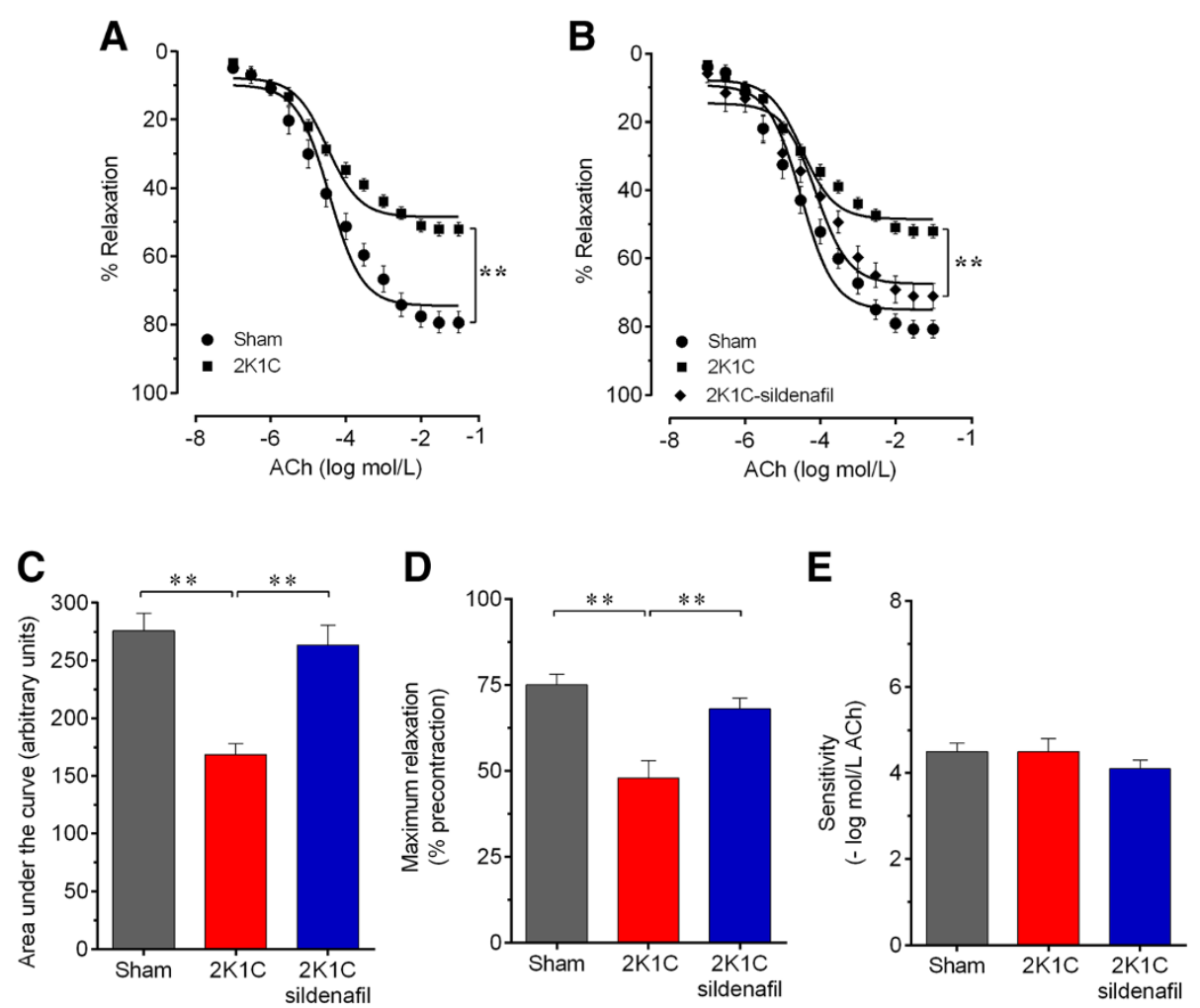

Figure 3 Effect of sildenafil treatment on the endothelial function. Acetylcholine-induced relaxation of mesenteric arterial bed preconstricted using norepinephrine, comparing $2 \mathrm{~K} 1 \mathrm{C}$ mice treated with sildenafil with non-treated $2 \mathrm{~K} 1 \mathrm{C}$ hypertensive and sham control mice (A and B). Bar graphs show the area under the curve (C), the maximum relaxation (Rmax) (D) and the sensitivity (pEC50) (E). Values are the means \pm SEM for 8-10 animals per group. ${ }^{* *} \mathrm{p}<0.01$, one- (C, D and E) and two-way (A and B) ANOVA.

Because endothelial dysfunction in cardiovascular pathologies is typically associated with 1 ) decreased NO production and/or increased metabolism, 2) decreased prostacyclin $\left(\mathrm{PGI}_{2}\right)$ synthesis, 3) increased production of contractile cyclooxygenase-derived prostanoids, 4) altered endothelium-dependent hyperpolarizing factor (EDHF) levels and 5) increased production of ROS $[15,22]$, we designed additional experiments to examine various molecular pathways.

The participation of ROS in the relaxation response to $\mathrm{ACh}$ was assessed via pre-incubation of the MABs in apocynin, an inhibitor of NADPH. Figure 4 summarizes the dose-response curves in response to $\mathrm{ACh}$ for the three groups. As expected, in sham mice (Figure 4A and D), apocynin blockade did not induce a significant change in the $\triangle$ AUC (+13 a.u., $\mathrm{p}>0.05)$. In contrast, the hypertensive $2 \mathrm{~K} 1 \mathrm{C}$ mice exhibited an improved vasodilation response to ACh (Figure 4B), as indicated by an increase in the $\triangle \mathrm{AUC}$ (+65 a.u., $\mathrm{p}<0.01$, Figure 4D). In the hypertensive $2 \mathrm{~K} 1 \mathrm{C}$ mice treated with sildenafil, in which the dose-response curve in response to ACh in the absence of apocynin treatment was similar to that of the Sham mice (Figure 4C), apocynin treatment did not induce a significant change in the $\triangle \mathrm{AUC}$ (Figure 4D). Similarly, preincubation of the
MABs with apocynin did not induce a significant change in the $\mathrm{R}_{\max }$ to ACh in Sham mice (from $73 \pm 5 \%$ to $80 \pm 2 \%$, $\Delta+10 \%, \mathrm{p}>0.05)$ or in $2 \mathrm{~K} 1 \mathrm{C}$ mice treated with sildenafil (from $75 \pm 2 \%$ to $69 \pm 3 \%, \Delta-8 \%, \mathrm{p}>0.05$ ). In contrast, in 2K1C hypertensive mice, apocynin treatment induced an improvement in the $\mathrm{R}_{\max }$ (from $49 \pm 2 \%$ to $64 \pm 3 \%, \Delta+$ $30 \%, \mathrm{p}<0.01$ ) (Figure 4E). However, there was no significant difference in the sensitivity $\left(\mathrm{pEC}_{50}\right)$ between the three groups of animals (Figure 4F). These data indicate that increased ROS production significantly contributes to the impairment of endothelium-dependent relaxation in MABs from hypertensive $2 \mathrm{~K} 1 \mathrm{C}$ mice and that sildenafil treatment restores the normal oxidative balance in these animals.

Figure 5 summarizes the data of the vasodilation doseresponse curves in response to $\mathrm{ACh}$ under the conditions of NOS blockade using L-NAME in MABs from the three groups of animals. Under L-NAME-mediated NOS blockade, the $\triangle \mathrm{AUC}$ was decreased in Sham mice $(-77 \pm 5$ a.u., Figure $5 \mathrm{~A}$ and $\mathrm{D}$ ) and mainly in the hypertensive $2 \mathrm{~K} 1 \mathrm{C}$ mice $(-26 \pm 4$ a.u., Figure $5 B$ and $D)$, and these alterations were ameliorated by treatment of the $2 \mathrm{~K} 1 \mathrm{C}$ mice with sildenafil $(-93 \pm 4$ a.u., Figure $5 \mathrm{C}$ and $\mathrm{E}, \mathrm{p}<0.01)$. The dose-response curves in response to $\mathrm{ACh}$ in the presence 

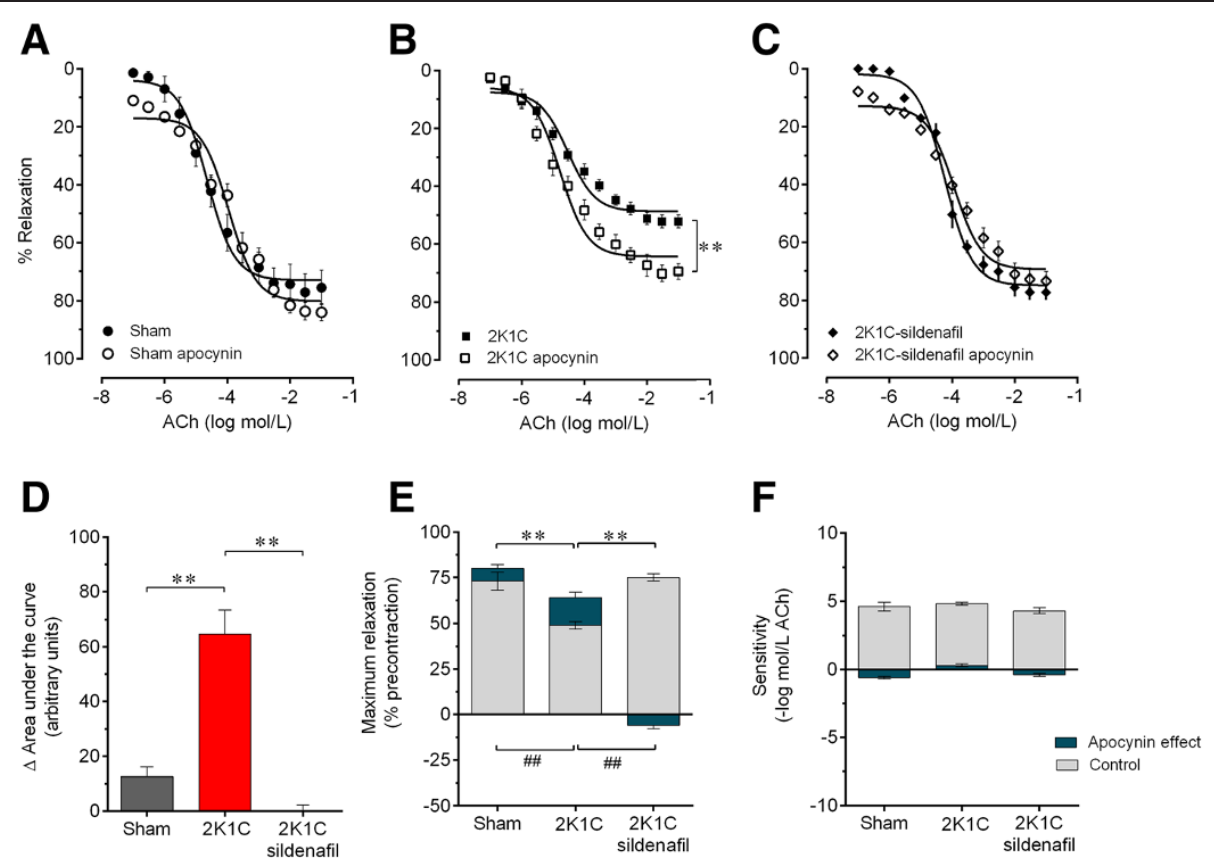

Figure 4 Contribution of reactive oxygen species to the endothelial dysfunction. Data show the effect of the blockade of $N A D(P) H$ oxidase activity with apocynin on the dose-response curve to acetylcholine (ACh) in Sham (A), non-treated 2K1C (B) and 2K1C mice treated with sildenafil (C) mice. Bar graphs show the area under the curve $(\mathbf{D})$, maximum response $(\mathbf{E})$ and the sensitivity $\left(\mathrm{pEC} \mathrm{C}_{50}\right)(\mathbf{E}$ and $\mathbf{F}$, gray color) and the relative changes induced by apocynin ( $\mathbf{E}$ and $\mathbf{F}$, blue color) in the groups of animals. Values are the means \pm SEM for $8-10$ animals per group. ${ }^{* *} p<0.01$ (gray bars) and $\# \mathrm{p}<0.01$ (apocynin effect, green bars), one- (D, E and F) and two-way (A, B and C) ANOVA.

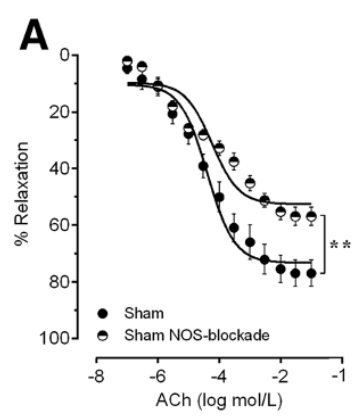

$\mathbf{B}$

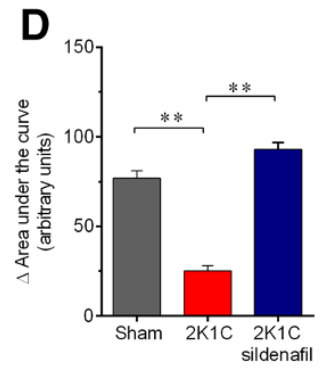

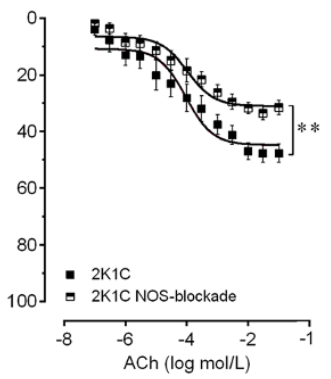

E

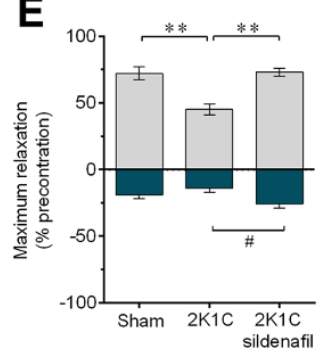

C

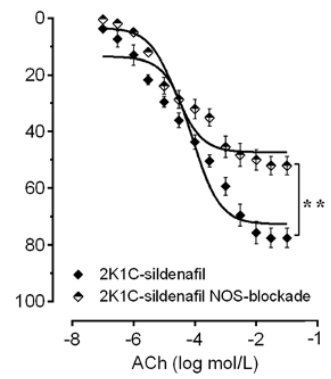

$\mathbf{F}$

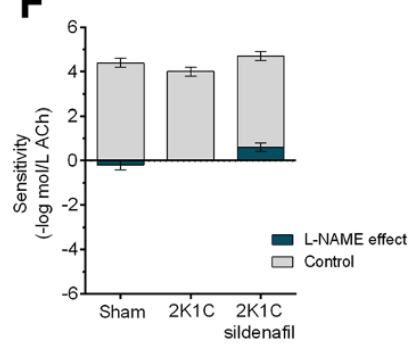

Figure 5 Contribution of nitric oxide to the endothelial function. Dose-response relaxation curves to acetylcholine (ACh) in Sham (A), non-treated 2K1C hypertensive (B) and sildenafil-treated 2K1C (C) mice with and without blockade of nitric oxide synthase (NOS) with L-NAME. Bar graphs show the area under the curve derived from the dose-response curves to $A C h(D)$, the maximum response $\left(R_{\max }\right)(\mathbf{E})$ and $p E C_{50}(\mathbf{F})$. Values are the means \pm SEM. ${ }^{* *} p<0.01$ and ${ }^{\#} p<0.05$ compared to the group indicated by the line; two-way ANOVA (A, B and C) and one-way ANOVA (D, E and F). 
of L-NAME displayed a significant reduction in the $R_{\max }$ in the Sham mice (from $72 \pm 5 \%$ to $53 \pm 3 \%, \Delta-19 \%$, p < 0.01 , Figure $5 \mathrm{E}$ ). In the non-treated $2 \mathrm{~K} 1 \mathrm{C}$ mice, in which the vasorelaxation response to ACh was already markedly impaired, L-NAME blockade caused a smaller but significant decrease in the perfusion pressure, as $R_{\max }$ was further decreased (from $45 \pm 4 \%$ to $31 \pm 2 \%, \Delta-14 \%, \mathrm{p}<0.01$, Figure $5 \mathrm{E}$ ). In the $2 \mathrm{~K} 1 \mathrm{C}$ mice treated with sildenafil, the dose-response curves in response to ACh in the presence of L-NAME displayed a similar alteration in the perfusion pressure (from $73 \pm 3 \%$ to $47 \pm 4 \%, \Delta-26 \%$, p < 0.01 , Figure $5 \mathrm{E}$ ) to that of the Sham mice. No significant difference in the $\mathrm{pEC}_{50}$ was detected between the three groups (Figure $5 \mathrm{~F}$ ). Taken together, these results indicate that treatment of hypertensive $2 \mathrm{~K} 1 \mathrm{C}$ mice with sildenafil restores the decreased $\mathrm{NO}$ bioavailability in the MAB to that of normotensive Sham mice.

To indirectly quantify the contribution of prostanoids and other pathways not involving $\mathrm{NO}$ or prostanoids to the relaxation response induced by $\mathrm{ACh}$, we designed an experiment in which two inhibitors, L-NAME and indomethacin, were applied (Figure 6). Thus, the difference in the AUC between treatment with both inhibitors and treatment with L-NAME alone indicates the contribution of the prostanoids pathway (Figure 6F), and difference between the AUC under control conditions and the AUC in the presence of both inhibitors indicates the contribution of EDHF and other unidentified vasodilatory pathways (Figure 6E). The dose-response curves in response to $\mathrm{ACh}$ under in the presence of both inhibitors were significantly shifted upward (reduced perfusion pressure, i.e., reduced vasodilation) in all three groups of animals, although to a lesser extent in the hypertensive $2 \mathrm{~K} 1 \mathrm{C}$ group (Figure $6 \mathrm{~B}$ ) and to a greater extent in the $2 \mathrm{~K} 1 \mathrm{C}$ group treated with sildenafil (Figure 6C) compared with the Sham group (Figure 6A). The AUC (before - after treatment with both inhibitors), as shown in Figure 6D), was significantly reduced in the Sham mice $(-122$ a.u., $\mathrm{p}<0.01)$ and was markedly increased in the hypertensive $2 \mathrm{~K} 1 \mathrm{C}$ mice $(50 \%, \mathrm{p}<0.01)$, but recovered by treatment with sildenafil $(-133$ a.u., $\mathrm{p}<0.01)$. The contribution of prostanoids to the change in the AUC was significantly reduced in the hypertensive $2 \mathrm{~K} 1 \mathrm{C}$ mice $(47 \%, \mathrm{p}<$ 0.01 ) compared with the Sham mice ( $45 \pm 4$ a.u.); sildenafil treatment restored these values to control levels ( $40 \pm 5$ a.u.) (Figure 6F). The contribution of EDHF and other unidentified pathways was greater than that of the prostanoids pathways, as indicated by the average values shown in Figure 6E. The $\triangle \mathrm{AUC}$ associated with EDHF and other unidentified vasodilation pathways was significantly reduced in the hypertensive $2 \mathrm{~K} 1 \mathrm{C}$ mice $(30 \%$, $\mathrm{p}<0.01$ ) compared with the Sham mice (Figure 6E). This difference was abolished by treatment with sildenafil. The $R_{\max }$ in the presence of both inhibitors was significantly decreased in all three groups (Figure 6G), although to a lesser extent in the hypertensive $2 \mathrm{~K} 1 \mathrm{C}$ group (from $42 \pm 4 \%$ to $31 \pm 2.0 \%, \Delta-11 \%, \mathrm{p}<0.01$ ) and to a greater extent in the $2 \mathrm{~K} 1 \mathrm{C}$ group treated with sildenafil (from $71 \pm 3 \%$ to $36 \pm 5 \%, \Delta-35 \%, \mathrm{p}<0.01$ ) compared with the Sham group (from $76 \pm 5 \%$ to $48 \pm 4 \%, \Delta-38 \%, \mathrm{p}<0.01$ ). The sensitivity $\left(\mathrm{pEC}_{50}\right)$ was similar between the three groups both before and after treatment with both inhibitors (between groups), but in the $2 \mathrm{~K} 1 \mathrm{C}$ mice treated with sildenafil, treatment with both inhibitors induced a significant decrease $(-20 \%, \mathrm{p}<0.05$, Figure $6 \mathrm{H})$.

The bar graph in Figure 7, which was generated using the AUCs from dose-response curves to ACh from Figures 3, 4,5 and 6 , displays the relative contribution of each molecular pathway to vasodilatory process (difference between the total AUC and the AUC after treatment with both LNAME and indomethacin) and the opposing effect of the ROS pathway. The total AUC of the Sham group ( $275 \pm 13$ a.u.) was considered as $100 \%$ and was used as the reference value for comparisons with the nontreated $2 \mathrm{~K} 1 \mathrm{C}$ group $(169 \pm 11$ a.u. $)$ and the $2 \mathrm{~K} 1 \mathrm{C}$ group treated with sildenafil ( $263 \pm 15$ a.u.). As shown, the contribution of the NO/cGMP pathway was markedly impaired in the hypertensive $2 \mathrm{~K} 1 \mathrm{C}$ mice $(34 \%)$, which were recovered by sildenafil treatment (121\%). The prostanoids/cAMP pathway, which includes $\mathrm{PGI}_{2}$ and other vasodilatory eicosanoids, was also substantially impaired in the hypertensive $2 \mathrm{~K} 1 \mathrm{C}$ mice (53\%), and sildenafil treatment attenuated this impairment (89\%). The residual area of the total AUC after treatment with both inhibitors (L-NAME and indomethacin) corresponds to the contribution of other known vasodilatory factors, such as EDHF $/ \mathrm{K}^{+}$channels, and, in our opinion, it could also include the Ang 1-7; this pathway was slightly attenuated (78\%) and was incompletely restored by sildenafil treatment $(86 \%)$. The ROS levels were markedly increased in the hypertensive $2 \mathrm{~K} 1 \mathrm{C}$ mice $(500 \%)$, and we found that its inhibitory effect on the vasodilation process was alleviated by sildenafil treatment (23\%).

\section{Flow cytometry analysis of oxidative stress in endothelial cells from $M A B$}

Intracellular $\cdot \mathrm{O}_{2}^{-}, \cdot \mathrm{ONOO}^{-}$and $\mathrm{NO}$ in endothelial cells were quantified by flow cytometry through DHE, HPF and DAF staining. Top panels of Figure 8 are typical histograms showing a rightward-shift in the log of DHE and HPF fluorescence in 2K1C hypertensive mice compared with Sham mice and contrasting with a leftward-shift observed in $2 \mathrm{~K} 1 \mathrm{C}$ animals treated with sildenafil. On the other hand, the typical histogram of NO production of the 2K1C mouse treated with sildenafil, showed a rightwardshift in the log of DAF fluorescence when compared with the $2 \mathrm{~K} 1 \mathrm{C}$ hypertensive mouse. As summarized in the bar graphs (Figure 8), endothelial cells isolated from $\mathrm{MAB}$ of 

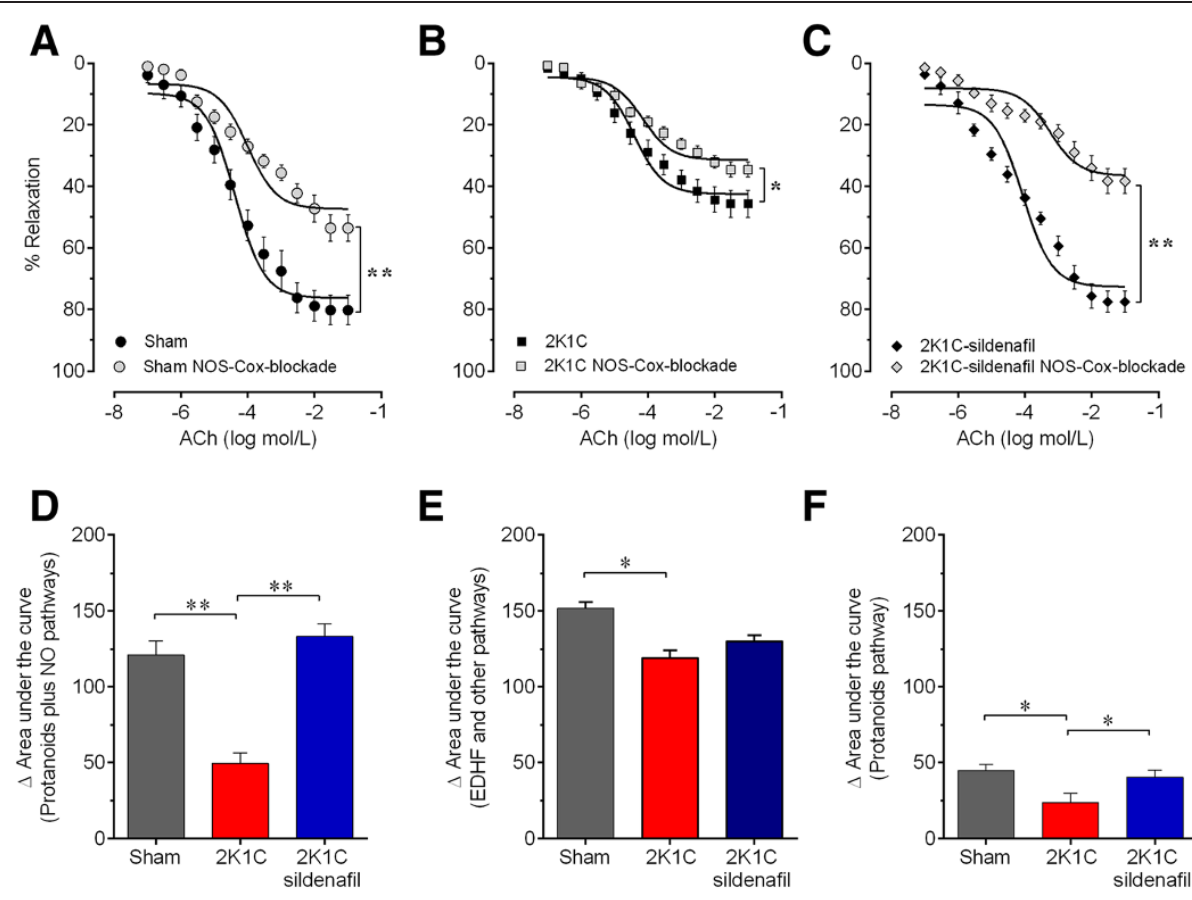

$\mathbf{E}$

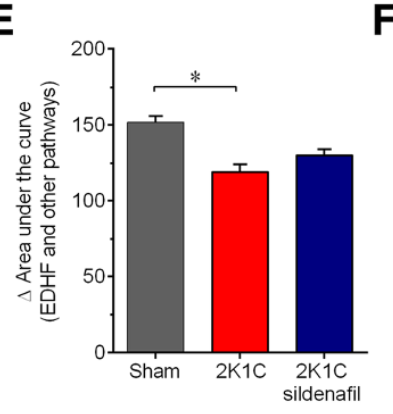

$\mathbf{F}$

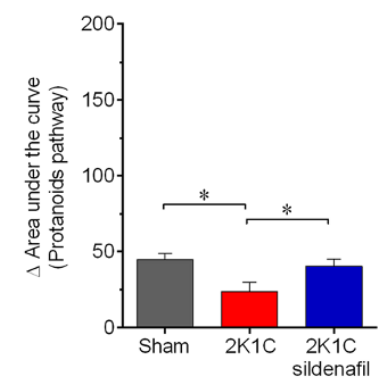

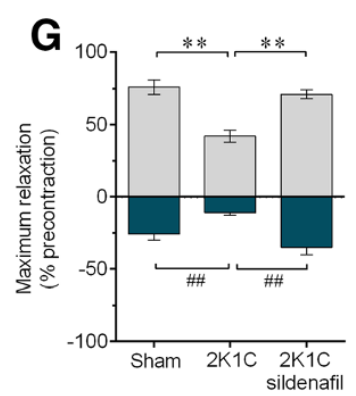

H

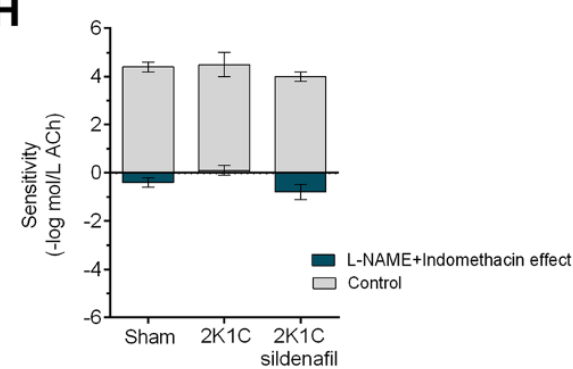

Figure 6 Contribution of prostanoids and other relaxing pathways to the endothelial dysfunction. A: dose-response relaxation curves to acetylcholine (ACh) in Sham (A), non-treated 2K1C hypertensive (B) and sildenafil-treated 2K1C (C) mice. Dose-response curves to ACh were obtained with and without the double blockade of NOS with L-NAME and of cyclooxygenases with indomethacin. Bar graphs show the area under the curve (AUC) after the double blockade (D), the total AUC minus the AUC after the double blockade (contribution of EDHF and other pathways, E) and the AUC derived from the AUC under double blockade minus the AUC under the L-NAME blockade (prostanoids pathway, $\mathbf{F}$ ). Graphs $\mathbf{G}$ and $\mathbf{H}$ show the effects of indomethacin on the maximum relaxation $\left(R_{\max }, \mathbf{G}\right)$ and sensitivity $\left(p E C_{50}, \mathbf{H}\right)$ and on these two parameters Values are the means \pm SEM for 8 to 10 animals per group. ${ }^{*} p<0.05,{ }^{*} p<0.05,{ }^{* *} p<0.01$ and ${ }^{\# \#} p<0.01$, compared with the group indicated by the line; two-way ANOVA (A, B and C) and one-way ANOVA (D-H).

2K1C mice exhibited a remarkable increase in $\cdot \mathrm{O}_{2}{ }^{-}$ and $\cdot \mathrm{ONOO}^{-}$levels $(41 \%$ and $76 \%$, respectively, $\mathrm{p}<$ $0.05)$ when compared with the levels of Sham mice (1252 \pm 81 and $1524 \pm 25$ a.u., respectively). However, the chronic treatment of $2 \mathrm{~K} 1 \mathrm{C}$ mice with sildenafil was able to decrease the production of $\cdot \mathrm{O}_{2}{ }^{-}$and $\cdot \mathrm{ONOO}^{-}$ to levels $(1266 \pm 25$ and $1518 \pm 40$ a.u., respectively, p < $0.05)$ similar to that observed in the Sham group. Additionally, sildenafil treatment of $2 \mathrm{~K} 1 \mathrm{C}$ mice restored the NO levels $(6310 \pm 172$ a.u., p < 0.05) when compared with Sham (6273 \pm 218 a.u.) and the non-treated 2K1C mice (1242 \pm 25 a.u.).

\section{Discussion}

Previous results from our laboratory [21] demonstrated by the first time that sildenafil repaired the hypoperfused kidney injury in $2 \mathrm{~K} 1 \mathrm{C}$ hypertensive mice by activation of the NO-mediated pathway. This pleiotropic protective role of sildenafil led us to investigate other additional beneficial effects of this drug on the systemic RAS and resistance vasculature in this model of hypertension. Our primary finding was that chronic treatment of these animals with this selective PDE5 inhibitor sildenafil restored the levels of BP and vascular relaxation to those of normotensive sham mice. Moreover, the present study 


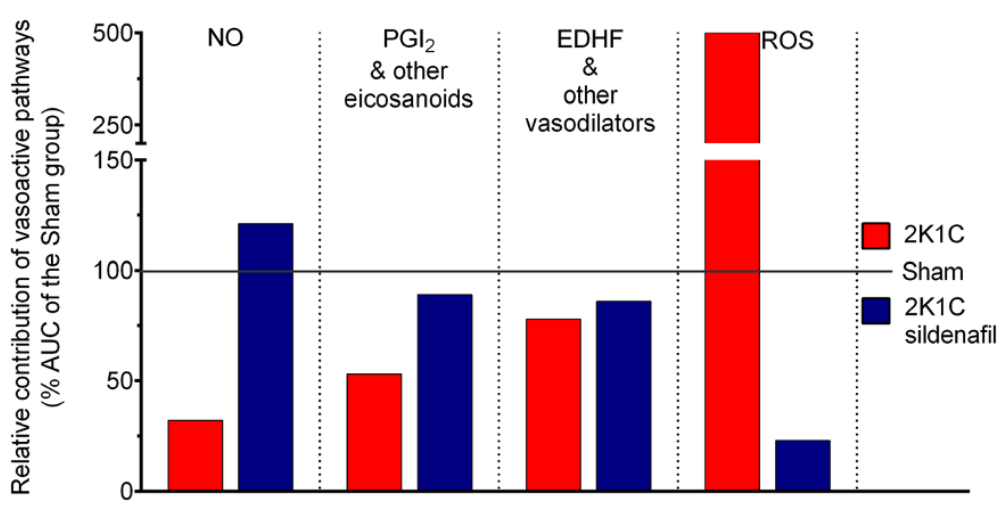

Figure 7 Schematic diagram illustrating the individual contribution of each endothelial pathway to the endothelial function in the RAS-dependent renovascular hypertension. Data show percentage of changes in the area under the curve (AUC) in relation to the Sham group (100\%) and was derived from the difference in the area under the dose-response curve to acetylcholine (Figures 3, 4, 5 and 6) before and after the blockade of the molecular pathways; endothelial nitric oxide (NO) synthase (with L-NAME), cyclooxygenases (Cox)/prostanoids such as prostacyclin $\left(\mathrm{PGI}_{2}\right.$ ) and other eicosanoids (with indomethacin), reactive oxygen species (ROS)/NADPH oxidase (with apocynin) and endothelialderived hyperpolarizing factor (EDHF) (residual response after double blockade with L-NAME and indomethacin).

is the first to reveal that the beneficial effects of sildenafil appear to be mediated by decreasing the levels of the vasoconstrictive and pro-oxidant peptide Ang II and increasing the levels of its physiological antagonist Ang 1-7.

A recent work from Navar's group and our collaborator Casarini's group [34] revealed that the maintenance of high blood pressure in $2 \mathrm{~K} 1 \mathrm{C}$ is dependent of an imbalance between high levels of ACE/Ang II and low levels of ACE2/Ang 1-7, both being influenced by renin activity $[16,35]$. In parallel, it has been reported that augmentation of chymase activity in the ischemic kidney of 2K1C rats [36] may be a mechanism related with ACEindependent intrarenal Ang II production. Moreover, previous studies have demonstrated that Ang II downregulates
ACE2 mRNA expression in some tissues, including the kidney $[37,38]$, which could be mediated by AT1 receptors $[39,40]$. Based on the above findings and on our studies in $2 \mathrm{~K} 1 \mathrm{C}$ hypertensive mice, we speculate that the repair of the stenotic kidney by sildenafil (administered for 14 days) was mediated by attenuation of renal baroreceptor activity, with consequent deactivation of the intrarenal RAS, as confirmed in the present study by decrease in intrarenal Ang I $(\sim 33 \%)$ and II ( $\sim 50 \%)$ and (contrasting) by increase in Ang 1-7 ( 15\%), as compared with $2 \mathrm{~K} 1 \mathrm{C}$ mice.

Regarding the plasma Ang I and II, our finding of normalized levels at the chronic phase was expected based on the fact that in the rat Ang-dependent renovascular hypertension has been separated in two phases [5]. The
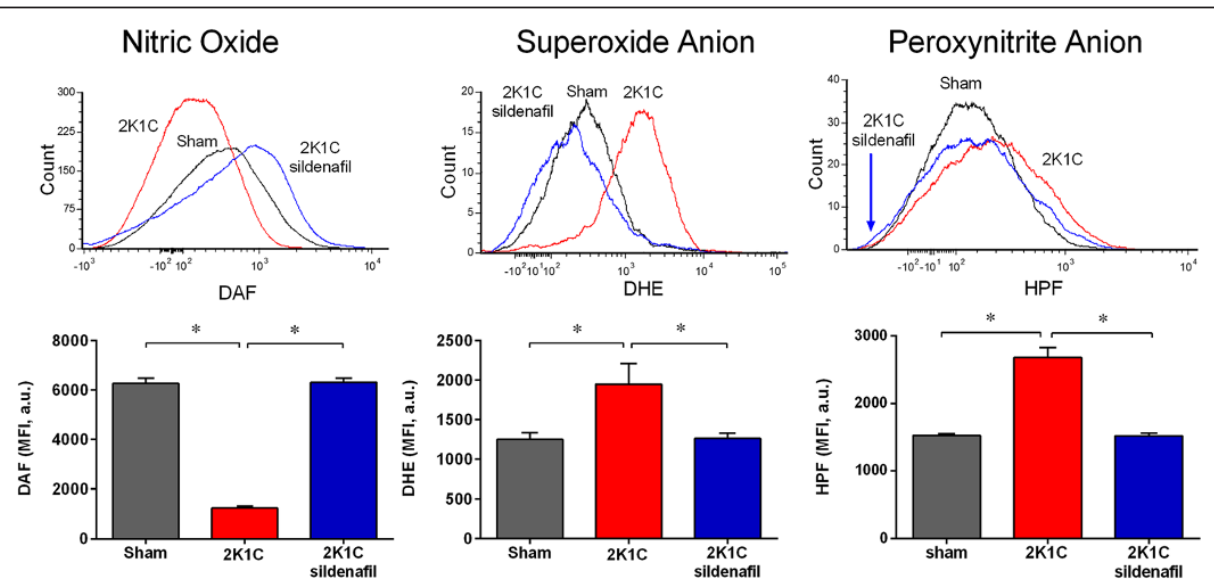

Figure 8 Superoxide anion production in mesenteric vascular beds. Top panel shows representative histograms from flow cytometric analysis using dihydroethidium (DHE), diaminofluorescein (DAF) and hydroxyphenyl fluorescein (HPF) in Sham, 2K1C hypertensive and sildenafil-treated 2K1C mice; the log fluorescence ( $X$ axis) illustrates the differences in intensity of fluorescence for the number of cells counted. Bar graph shows augmented production of superoxide anions and peroxynitrite in $2 \mathrm{~K} 1 \mathrm{C}$ hypertensive mice compared with Sham mice and sildenafil treatment restored the normal values. On the other hand, $2 \mathrm{~K} 1 \mathrm{C}$ mice presented impairment of nitric oxide production compared with sham mice, and sildenafil treatment restored the normal levels. Values are median fluorescence intensity (MFI, in arbitrary units) \pm SEM for 5 animals per group. * $p<0.05$ (one-way ANOVA). 
initial phase is related to the development of hypertension, which occurs from the first day following the placement of the clip to the $14^{\text {th }}$ day, when the plasma levels of Ang II peak. The late (second) phase is related to the maintenance of hypertension, which has been evaluated at approximately 28 days after renal artery clipping, and that shows stabilized plasma levels of Ang II [5]. In the mouse model, the few available studies have reported an increase in renin activity and the levels of Ang I ( $50 \%)$ [20,41], Ang II ( 350\%) [20,30,42] and Ang 1-7 in plasma ( 110\%) [20] during the first phase of renovascular hypertension (14 days following the clip placement). During the second phase of $2 \mathrm{~K} 1 \mathrm{C}$ hypertensive mice, neither increased plasma renin activity nor elevated levels of Ang I [41] or Ang II [42,43] has been detected, justifying the similar profile founded in this study. Altogether, the above data extend to the mice the timecourse profile of Ang that has been demonstrated by Navar's research group in the rat [5]. Surprisingly, we observed that sildenafil treatment increased plasma levels of Ang 1-7 ( 45\%), which is known to counterbalance the deleterious effects elicited by Ang II [16,35]. Based on our findings, we speculate that the Ang 1-7 generated by the ACE2-mediated degradation of Ang II may also limit the intrarenal uptake of Ang II, as discussed above. It should be noted that, in a review of contemporary literature, it is notable a vast diversity in the methods that have been used for the analysis of the RAS in the few studies using the $2 \mathrm{~K} 1 \mathrm{C}$ mouse model, confounding the comparison of the plasma and tissue levels of RAS peptides. As a solution for this discrepancy, we considered that it would be most appropriate to compare our detected values in the hypertensive $2 \mathrm{~K} 1 \mathrm{C}$ mice and the $2 \mathrm{~K} 1 \mathrm{C}$ mice treated with sildenafil to the average values in the Sham mice, which were normalized to $100 \%$; similarly, we will compare the data found by us and others using relative (\%) values.

In the present study, $2 \mathrm{~K} 1 \mathrm{C}$ mice exhibited a high $\mathrm{BP}$, approximately $20 \%$ higher than that of the Sham mice, in agreement with other studies reporting similar increases (20-25\%) [12,15,30,31,41-45]. The high BP was accompanied by tachycardia, which is consistent with other reports [20,21,41]. As expected, and based on previous studies using the rat model [21,46-48], we found that sildenafil normalized the BP and HR. Moreover, the novelty of the present study is that according to the profile of intrarenal and plasma Ang that we observed, it could be speculated that these beneficial effects of sildenafil are partially mediated by the reciprocal changes in Ang, i.e., a decrease of Ang II and increase of Ang 1-7. This hypothesis may be reinforced by the finding that chronic treatment of spontaneously hypertensive rats (SHR) with Mas receptor agonists or with Ang 1-7 led to vasorelaxation, anti-hypertensive and cardioprotective effects [49,50].
Additionally, the plasma levels of Ang 1-7 were increased during treatment with ACE inhibitors or AT1 receptor blockers, indicating a potential dependence of the antihypertensive effects of those compounds on Ang 1-7 $[18,39]$. Despite of our results demonstrate a drop in Ang II, we cannot rule out the possibility the participation of AT2 receptor in this model of hypertension, since this protein can stimulates NO signaling [51], potentiating the effects of sildenafil. This hypothesis is corroborated by other recent studies that demonstrated the importance of AT2 receptor in renovascular hypertension [52,53]. Thus, targeting the ACE2-Ang (1-7)-Mas and AT2 receptor axis using new pharmacological tools, such as sildenafil, which we used in the current study, may represent a novel therapeutic strategy for renovascular hypertension.

It has been demonstrated that the interruption of the ACE2-Ang (1-7)-Mas axis is an underlying mechanism responsible for the worsening of the developmental and maintenance phases in 2K1C Mas knockout mice [39], as well as impairing the baroreflex control, endothelial function and the balance of NO/ROS in normotensive mice $[40,41]$. In parallel, recent data have demonstrated specific and beneficial effects of AT2 receptor via central areas in hypertensive rats [54]. Considering the evidence that sildenafil crosses the blood-brain barrier $[55,56]$ and that it affects the angiotensin profile, one cannot rule out the possibility of also a central action on the sympathetic/parasympathetic drive. In this context, although recent studies have shown an increased sympathetic drive imposed on the cardiovascular system by sildenafil in both rats [56] and humans [57,58], we speculate that in our study (in which sildenafil was chronically administered) its systemic antioxidant effects overtook the possible undesirable sympathetic-mediated effects.

Endothelial dysfunction is an important abnormal function commonly observed in cardiovascular diseases, including atherosclerosis [22] and various models of arterial hypertension [15]. Previous studies by our group revealed that the MAB exhibits an increased response to vasoconstrictors and a decreased response to vasodilators in RASdependent hypertensive rats [24,59] and mice [15]. Thus, in the current study, we designed an experiment to evaluate the effects of sildenafil treatment on endothelial dysfunction in hypertensive $2 \mathrm{~K} 1 \mathrm{C}$ mice. We selected the $2 \mathrm{~K} 1 \mathrm{C}$ model that was developed by Goldblatt decades ago because endothelial dysfunction is an early characteristic of RAS-dependent 2K1C-mediated hypertension [15,60]. As expected, ACh evoked endothelium-dependent relaxation, which was greatly diminished in the $2 \mathrm{~K} 1 \mathrm{C}$ mice. However, no significant difference was detected in the dose-response curve to the NO donor SNP, indicating that vascular dysfunction may be due to dysfunctional molecular pathways in endothelial cells but not in vascular smooth muscle cells. This result is in agreement with 
studies showing that impaired endothelium-dependent vasorelaxation is associated with the second phase of chronic 2K1C hypertension in the rat model [5,61]. Because we hypothesized that $2 \mathrm{~K} 1 \mathrm{C}$-induced endothelial dysfunction may be improved by chronic treatment with sildenafil, standard experiments using pharmacological inhibitors were designed to assess the relative contribution of each molecular pathway to the relaxation responses to $\mathrm{ACh}$ in the $\mathrm{MAB}$ and the effectiveness of sildenafil in restoring or improving endothelial function in the $2 \mathrm{~K} 1 \mathrm{C}$ mice.

The relative importance of vasoactive substances, such as NO, $\mathrm{PGI}_{2}, \mathrm{EDHF}$ and ROS, depends on the size of the blood vessels and the experimental animal. Studies have shown that in the rat, NO is the primary contributor to ACh-induced vasodilation in the aorta, whereas EDHF plays a predominant role in resistance vessels [62]. Our data show that in both the wild type and hypertensive $2 \mathrm{~K} 1 \mathrm{C}$ mice, the EDHF pathway was the primary contributor and was scarcely altered in the endothelium-dependent relaxation response to $\mathrm{ACh}$ in the MAB. This finding corroborates a previous study showing that EDHF-mediated dilatory responses were unaffected in mesenteric resistance vessels in RAS-dependent hypertensive mice [63]. Moreover, our data show that in the vasodilator pathway, the impairment of NO/cGMP was the primary contributor to endothelial dysfunction, followed by $\mathrm{PGI}_{2}$, as determined using hypertensive $2 \mathrm{~K} 1 \mathrm{C}$ mice. Indeed, the contribution of $\mathrm{NO}$ and $\mathrm{PGI}_{2}$ to endothelial function in the $2 \mathrm{~K} 1 \mathrm{C}$ mice was reduced to approximately $35 \%$ and $50 \%$, respectively, of that in the Sham mice. By blocking NAD $(\mathrm{P}) \mathrm{H}$ using apocynin, we also found that the levels of ROS, which have opposing effects to those of $\mathrm{NO}$ and $\mathrm{PGI}_{2}$, were increased approximately 6 -fold in the $2 \mathrm{~K} 1 \mathrm{C}$ mice, in agreement with the rat model of renovascular hypertension [48,64]. This finding may be because high BP (enhanced shear stress) and activation of the RAS have been shown to increase ROS production by $\mathrm{NAD}(\mathrm{P}) \mathrm{H}$ oxidase via the $\mathrm{AT}_{1}$ receptor axis, decreasing $\mathrm{NO}$ bioavailability in the $2 \mathrm{~K} 1 \mathrm{C}$ mice $[27,30,45,65]$. The hypothesis that it occurs an imbalance between $\mathrm{NO}$ and $\mathrm{O}_{2}$ levels in the endothelial cells isolated from $M A B$, but not only systemically $[21,30,31]$, was confirmed in a separated set of experiments by flow cytometry in the present study. Additionally, by using the HPF staining, we found in renovascular hypertensive mice an increase of endothelial production of peroxynitrite, which is derived from the reaction of $\mathrm{NO}$ with the superoxide anion. Taken together, these results suggest a relevant role of impairments of the NOS/cGMP and prostanoid/cAMP pathways and the activation of the ROS/cGMP pathway in the endothelial dysfunction observed in RAS-dependent hypertension [66].

The second novel finding based on endothelial function analysis is that sildenafil recovered endothelial function to normal levels, as indicated by the parameters of the dose-response curve to ACh $\left(\mathrm{R}_{\max }\right.$ and AUC) and flow cytometry analysis of ROS. The recovery of endothelial function by sildenafil treatment primarily occurred due to a marked increase in the vasodilatory contribution of $\mathrm{NO}$ and a marked decrease in the levels of superoxide and (consequently) peroxynitrite anions. Recent data have shown that this vasodilator effect of sildenafil may involve indirect mechanisms, such as upregulation of $\mathrm{BH}_{4}$ and soluble guanylate cyclase (sGC) enzyme, besides the inhibition of NADPH oxidase activity, leading to the increase of NO bioavailability [67]. These findings corroborate the notion that the inhibition of PDE5 in the vessels in smooth muscle directly enhances the NO/cGMP signaling pathway by inhibiting cGMP degradation and subsequently facilitating vessel relaxation [68].

\section{Conclusion}

In conclusion, our data show that the chronic treatment of Ang-induced renovascular hypertensive mice with the PDE5 inhibitor sildenafil leads to a decrease in high BP and tachycardia, probably by decreasing the levels of plasma and intrarenal Ang II and increasing the levels of its physiological antagonist Ang 1-7. Additionally, sildenafil was able to abolish the endothelial dysfunction and the increased production of $\mathrm{O}_{2}{ }^{-}$of resistance vessels and then restoring the NO/ROS balance. The above data and interpretation indicate that the activation of the ACE2-Ang (1-7)-Mas axis by sildenafil may represent a novel therapeutic target in the context of endothelial dysfunction. Therefore, the present data revealing the beneficial effects of sildenafil support the concept that this inhibitor of PDE5 could be included in the hallmark of anti-hypertensive agents currently available, especially as an additional drug in patients with resistant hypertension despite the use of three or more drugs and in patients with endothelial dysfunction and kidney disease.

\section{Limitations and perspectives}

Although the present study was designed to assess the functional beneficial effects of sildenafil, a limitation is that our experiments did not completely elucidate the mechanisms underlying the specific molecular pathways by which sildenafil exerts its beneficial effects; we plan to address this issue in further studies. However, this translational research is of clinical relevance because it reveals new concept of interaction of sildenafil with the RAS and opens the perspective of using sildenafil to stimulate the production of Ang 1-7 as a new therapeutic approach for the treatment of renovascular hypertension an endothelial dysfunction, as well as for resistant hypertension.

\section{Abbreviations}

2K1C: Two-kidney, one-clip; ACh: Acetylcholine; ACE: Angiotensin converting enzyme; Ang II: Angiotensin; BP: Blood pressure; DHE: Dihydroethidium; EDHF: Endothelium-derived hyperpolarizing factor; eNOS: Endothelial nitric 
oxide synthase; HR: Heart rate; L-NAME: N-nitro-L-arginine methyl ester; MAB: Mesenteric arterial bed; MAP: Mean arterial blood pressure; NAD(P) $\mathrm{H}$ : Nicotinamide adenine dinucleotide phosphate; NO: Nitric oxide; PDE: Phosphodiesterase; RAS: Renin-angiotensin system; ROS: Reactive oxygen species; SNP: Sodium nitroprusside.

\section{Competing interests}

The authors declare that they have no competing interest.

\section{Authors' contributions}

ATD, ALG, ASC and JCF carried out experimental analysis and acquisition of data, analysis and interpretation of the data and drafted the manuscript. ZP and DEC carried out the protocol of analysis of Angiotensin II at the Federal University of Sao Paulo. CMB participated in the study's design and in the critical revision of the manuscript. IBSG co-supervised the graduated students and revised the manuscript. BPC and TMCP participated in the supervision and in the critical revision of the manuscript. SSM and ECV contributed to the conception, design and supervision of the study and interpretation of data. All authors read and approved the final version of the manuscript.

\section{Acknowledgements}

ECV is supported by the National Council for the Development of Science and Technology (CNPq, Ref. 302582/2011-8 and 476525/2012-8 Grants) and the State Agency for the Development of Science and Technology (FAPES/ Universal 012/2011/Proc. 54498465). SSM is supported by the National Council for the Development of Science and Technology (CNPq, Ref.305188/ 2012-7 Grant) and the State Agency for the Development of Science and Technology (FAPES/CNPq/Pronex Grant 012/2009). ALG is supported by the National Council for the Development of Science and Technology (CNPq, Ref. 473177/2013-7 Grant).

\section{Author details}

'Laboratory of Translational Physiology, Health Sciences Center, Federal University of Espirito Santo, Vitoria, ES, Brazil. ${ }^{2}$ Emescam School of Health Sciences, Vitoria, ES, Brazil. ${ }^{3}$ Department of Medicine, Nephrology Division, Federal University of Sao Paulo, Sao Paulo, SP, Brazil. ${ }^{4}$ Pharmaceutical Sciences Graduate Program, Health Sciences Center, Federal University of Espirito Santo, Vitoria, ES, Brazil. 'D Department of Physiology and Pathology, Health Sciences Center, Federal University of Paraiba, João Pessoa, PB, Brazil. ${ }^{6}$ Pharmaceutical Sciences Graduate Program, University Vila Velha (UW), Vila Velha, ES, Brazil. ${ }^{7}$ Federal Institute of Education, Science and Technology (IFES), Vila Velha, ES, Brazil.

Received: 17 June 2014 Accepted: 30 August 2014

Published online: 16 September 2014

\section{References}

1. Chokshi NP, Grossman E, Messerli FH: Blood pressure and diabetes: vicious twins. Heart 2013, 99(8):577-585.

2. Silva BR, Pernomian L, Bendhack LM: Contribution of oxidative stress to endothelial dysfunction in hypertension. Front Physiol 2012, 3:441.

3. Campagnaro BP, Gava AL, Meyrelles SS, Vasquez EC: Cardiac-autonomic imbalance and baroreflex dysfunction in the renovascular angiotensindependent hypertensive mouse. Int J Hypertens 2012, 2012:968123.

4. Faselis C, Doumas M, Papademetriou V: Common secondary causes of resistant hypertension and rational for treatment. Int J Hypertens 2011, 2011:236239.

5. Navar LG, Zou L, Von Thun A, Tarng Wang C, Imig JD, Mitchell KD: Unraveling the mystery of Goldblatt Hypertension. News Physio/ Sci 1998 13:170-176.

6. Piecha G, Wiecek A, Januszewicz A: Epidemiology and optimal management in patients with renal artery stenosis. J Nephro/ 2012, 25(6):872-878.

7. Elliott WJ: Renovascular hypertension: an update. J Clin Hypertens 2008 10(7):522-533.

8. Carey RM: Resistant hypertension. Hypertension 2013, 61(4):746-750

9. Vassallo DV, Vasquez EC, Cabral AM: Contractile performance of papillary muscles of renovascular hypertensive and isoproterenol-pretreated rats. Pharmacol Res Commun 1988, 20(1):61-72.
10. Abreu GR, Futuro-Neto HA, Cabral AM, Vasquez EC: L-arginine restores the effect of ouabain on baroreceptor activity and prevents hypertension. Hypertension 1999, 34(4 Pt 2):729-732

11. Pereira TM, Balarini CM, Silva IV, Cabral AM, Vasquez EC, Meyrelles SS: Endogenous angiotensin II modulates nNOS expression in renovascular hypertension. Braz J Med Biol Res 2009, 42(7):685-691.

12. Nogueira BV, Peotta VA, Meyrelles SS, Vasquez EC: Evaluation of aortic remodeling in apolipoprotein E-deficient mice and renovascular hypertensive mice. Arch Med Res 2007, 38(8):816-821.

13. Gava AL, Peotta VA, Cabral AM, Vasquez EC, Meyrelles SS: Overexpression of eNOS prevents the development of renovascular hypertension in mice. Can J Physiol Pharmacol 2008, 86(7):458-464.

14. Peotta VA, Gava AL, Vasquez EC, Meyrelles SS: Evaluation of baroreflex control of heart rate in renovascular hypertensive mice. Can J Physiol Pharmacol 2007, 85(8):761-766.

15. Arruda RM, Peotta VA, Meyrelles SS, Vasquez EC: Evaluation of vascular function in apolipoprotein $\mathrm{E}$ knockout mice with angiotensin-dependent renovascular hypertension. Hypertension 2005, 46:932-936.

16. Santos RA, Ferreira AJ, Verano-Braga T, Bader M: Angiotensin-converting enzyme 2, angiotensin-(1-7) and Mas: new players of the reninangiotensin system. J Endocrinol 2013, 216(2):R1-R17.

17. Ferreira AJ, Santos RA: Cardiovascular actions of angiotensin-(1-7). Braz $J$ Med Biol Res 2005, 38:499-507.

18. Ferrario CM: Angiotensin-converting enzyme 2 and angiotensin-(1-7): an evolving story in cardiovascular regulation. Hypertension 2006, 47(3):515-521.

19. Sihn G, Rousselle A, Vilianovitch L, Burckle C, Bader M: Physiology of the (pro)renin receptor: Wnt of change? Kidney Int 2010, 78(3):246-256.

20. Nogueira BV, Palomino Z, Porto ML, Balarini CM, Pereira TM, Baldo MP, Casarini DE, Meyrelles SS, Vasquez EC: Granulocyte colony stimulating factor prevents kidney infarction and attenuates renovascular hypertension. Cell Physiol Biochem 2012, 29(1-2):143-152.

21. Dias AT, Rodrigues BP, Porto ML, Gava AL, Balarini CM, Freitas FP, Palomino Z, Casarini DE, Campagnaro BP, Pereira TM, Meyrelles SS, Vasquez EC: Sildenafil ameliorates oxidative stress and DNA damage in the stenotic kidneys in mice with renovascular hypertension. J Trans/ Med 2014, 12:35.

22. Meyrelles SS, Peotta VA, Pereira TM, Vasquez EC: Endothelial dysfunction in the apolipoprotein E-deficient mouse: insights into the influence of diet, gender and aging. Lipids Health Dis 2011, 10:211.

23. Cola MS, Gava AL, Meyrelles SS, Vasquez EC: Endothelial dysfunction of resistance vessels in female apolipoprotein E-deficient mice. Lipids Health Dis 2010, 9:51

24. de Carvalho MH, Nigro D, Scivoletto R, Barbeiro HV, de Oliveira MA, de Nucci G, Fortes ZB: Comparison of the effect of endothelin on microvessels and macrovessels in Goldblatt II and deoxycorticosterone acetate-salt hypertensive rats. Hypertension 1990, 15(2 Suppl):168-171.

25. Fortes ZB, Costa SG, Nigro D, Scivoletto R, de Oliveira MA, de Carvalho MH: Effect of indomethacin on the microvessel reactivity of two-kidney, one-clip hypertensive rats. Arch Int Pharmacodyn Ther 1992, 316:75-89.

26. Raja SG, Nayak SH: Sildenafil: emerging cardiovascular indications. Ann Thorac Surg 2004, 78(4):1496-1506.

27. Balarini CM, Leal MA, Gomes IBS, Pereira TMC, Gava AL, Meyrelles SS, Vasquez EC: Sildenafil restores endothelial function in the apolipoprotein E knockout mouse. J Trans/ Med 2013, 11:3.

28. Montani D, Chaumais MC, Savale L, Natali D, Price LC, Jaïs X, Humbert M Simonneau G, Sitbon O: Phosphodiesterase type 5 inhibitors in pulmonary arterial hypertension. Adv Ther 2009, 26(9):813-825.

29. Rodrigues BP, Campagnaro BP, Balarini CM, Pereira TM, Meyrelles SS, Vasquez EC: Sildenafil ameliorates biomarkers of genotoxicity in an experimental model of spontaneous atherosclerosis. Lipids Health Dis 2013, 28:12. 128

30. Campagnaro BP, Tonini CL, Nogueira BV, Casarini DE, Vasquez EC, Meyrelles SS: DNA damage and augmented oxidative stress in bone marrow mononuclear cells from angiotensin-dependent hypertensive mice. Int $J$ Hypertens 2013, 2013:305202.

31. Campagnaro BP, Tonini CL, Doche LM, Nogueira BV, Vasquez EC, Meyrelles SS: Renovascular hypertension leads to DNA damage and apoptosis in bone marrow cells. DNA Cell Biol 2013, 32(8):458-466.

32. Walker DK, Ackland MJ, James GC, Muirhead GJ, Rance DJ, Wastall P, Wright PA: Pharmacokinetics and metabolism of sildenafil in mouse, rat, rabbit, dog and man. Xenobiotica 1999, 29(3):297-310.

33. Mattson DL: Comparison of arterial blood pressure in different strains of mice. Am J Hypertens 2001, 14(5 Pt 1):405-408. 
34. Prieto MC, González-Villalobos RA, Botros FT, Martin VL, Pagán J, Satou R, Lara LS, Feng Y, Fernandes FB, Kobori H, Casarini DE, Navar LG: Reciprocal changes in renal ACE/Ang II and ACE2/ANG 1-7 are associated with enhanced collecting duct renin in Goldblatt hypertensive rats. Am J Physiol Renal Physiol 2011, 300:F749-F755.

35. Santos RA, Ferreira AJ: Angiotensin-(1-7) and the renin-angiotensin system. Curr Opinion Nephrol Hypertens 2007, 16:122-128.

36. Sadjadi J, Kramer GL, Yu CH, Burress Welborn M 3rd, Chappell MC, Gregory Modrall J: Angiotensin converting enzyme-independent angiotensin ii production by chymase is up-regulated in the ischemic kidney in renovascular hypertension. J Surg Res 2005, 127(2):65-69.

37. Ferrario CM, Jessup J, Chappell MC, Averill DB, Brosnihan KB, Tallant EA, Diz $\mathrm{DI}$, Gallagher PE: Effect of angiotensin-converting enzyme inhibition andangiotensin II receptor blockers on cardiac angiotensin-converting enzyme 2. Circulation 2005, 111(20):2605-2610.

38. Gallagher PE, Chappell MC, Ferrario CM, Tallant EA: Distinct roles for ANG II and ANG-(1-7) in the regulation of angiotensin-converting enzyme 2 in rat astrocytes. Am J Physiol Cell Physiol 2006, 290(2):C420-C426.

39. Chappell MC, Marshall AC, Alzayadneh EM, Shaltout HA, Diz DI: Update on the angiotensin converting enzyme 2-angiotensin (1-7)-Mas receptor axis: fetal programing, sex differences, and intracellular pathways. Front Endocrinol (Lausanne) 2014, 4:201.

40. Koka V, Huang XR, Chung AC, Wang W, Truong LD, Lan HY: Angiotensin II up-regulates angiotensin I-converting enzyme (ACE), but down-regulates ACE2 via the AT1-ERK/p38 MAP kinase pathway. Am J Pathol 2008, 172(5):1174-1183.

41. Hartono SP, Knudsen BE, Zubair AS, Nath KA, Textor SJ, Lerman LO, Grande JP: Redox signaling is an early event in the pathogenesis of renovascular hypertension. Int J Mol Sci 2013, 14(9):18640-18656.

42. Cervenka L, Vanecková I, Husková Z, Vanourková Z, Erbanová M, Thumová M, Skaroupková P, Opocenský M, Malý J, Chábová VC, Tesar V, Bürgelová M, Viklický O, Teplan V, Zelízko M, Kramer HJ, Navar LG: Pivotal role of angiotensin II receptor subtype $1 \mathrm{~A}$ in the development of two-kidney, one-clip hypertension: study in angiotensin II receptor subtype 1A knockout mice. J Hypertens 2008, 26(7):1379-1389.

43. Rakušan D, Bürgelová M, Vaněčková I, Vaňourková Z, Husková Z, Skaroupková P, Mrázová I, Opočenský M, Kramer HJ, Netuka I, Malý J, Alenina N, Bader M, Santos RA, Cervenka L: Knockout of angiotensin 1-7 receptor Mas worsens the course of two-kidney, one-clip Goldblatt hypertension: roles of nitric oxide deficiency and enhanced vascular responsiveness to angiotensin II. Kidney Blood Press Res 2010, 33(6):476-488.

44. Wiesel P, Mazzolai L, Nussberger J, Pedrazzini T: Two-kidney, one clip and one-kidney, one clip hypertension in mice. Hypertension 1997, 29:1025-1030.

45. Salguero G, Akin E, Templin C, Kotlarz D, Doerries C, Landmesser U, Grote K, Schieffer B: Renovascular hypertension by two-kidney one-clip enhances endothelial progenitor cell mobilization in a p47phox-dependent manner. J Hypertens 2008, 26(2):257-268.

46. Castro MM, Rizzi E, Rascado RR, Nagassaki S, Bendhack LM, Tanus-Santos JE: Atorvastatin enhances sildenafil-induced vasodilation through nitric oxide-mediated mechanisms. Eur J Pharmacol 2004, 498(1-3):189-194.

47. Neto-Neves EM, Dias-Junior CA, Uzuelli JA, Pereira RP, Spiller F, Czaikoski PG, Tanus-Santos JE: Sildenafil improves the beneficial hemodynamic effects exerted by atorvastatin during acute pulmonary thromboembolism. Eur J Pharmacol 2011, 670(2-3):554-560.

48. Guimarães DA, Rizzi E, Ceron CS, Pinheiro LC, Gerlach RF, Tanus-Santos JE: Atorvastatin and sildenafil lower blood pressure and improve endothelial dysfunction, but only atorvastatin increases vascular stores of nitric oxide in hypertension. Redox Biol 2013, 1(1):578-585.

49. Savergnini SQ, Beiman M, Lautner RQ, de Paula-Carvalho V, Allahdadi $K$, Pessoa DC, Costa-Fraga FP, Fraga-Silva RA, Cojocaru G, Cohen Y, Bader M, de Almeida AP, Rotman G, Santos RA: Vascular relaxation, antihypertensive effect, and cardioprotection of a novel peptide agonist of the MAS receptor. Hypertension 2010, 56(1):112-120.

50. Shah A, Oh YB, Lee SH, Lim JM, Kim SH: Angiotensin-(1-7) attenuates hypertension in exercise-trained renal hypertensive rats. Am J Physiol Heart Circ Physiol 2012, 302(11):H2372-H2380.

51. Andresern BT, Shome K, Jackson EK, Romero GG: AT2 receptors cross talk with AT1 receptors through a nitric oxide- and RhoA-dependent mechanism resulting in decreased phospholipase D activity. Am J Physiol Renal Physiol 2005, 288(4):F763-F770.
52. Babu CS, Kalaivani P, Ranju V, Sathiya S, Anbarasi C, Mahadevan MV, Vijayakumar H, Sunil AG, Thanikachalam S: Venthamarai chooranam, a polyherbal Siddha medicine, alleviates hypertension via AT1R and eNOS signaling pathway in $2 \mathrm{~K} 1 \mathrm{C}$ hypertensive rats. Exp Biol Med (Maywood) 2014, 239(6):758-769.

53. Hiyoshi H, Yayama K, Takano M, Okamoto H: Angiotensin type 2 receptor-mediated phosphorylation of eNOS in the aortas of mice with 2-kidney, 1-clip hypertension. Hypertension 2005, 45(5):967-973.

54. Blanch GT, Freiria-Oliveira AH, Speretta GF, Carrera EJ, Li H, Speth RC, Colombari E, Sumners C, Colombari DS: Increased Expression of Angiotensin II Type 2 Receptors in the Solitary-Vagal Complex Blunts Renovascular Hypertension. Hypertension 2014, (Epub ahead of print).

55. Milman HA, Arnold SB: Neurologic, psychological, and aggressive disturbances with sildenafil. Ann Pharmacother 2002, 36(7-8):1129-1134.

56. Fazan R Jr, Huber DA, Silva CA, da Silva VJ D, Salgado MC, Salgado HC: Sildenafil acts on the central nervous system increasing sympathetic activity. J Appl Physiol (1985) 2008, 104(6):1683.

57. Dopp JM, Agapitov AV, Sinkey CA, Haynes WG, Phillips BG: Sildenafil increases sympathetically mediated vascular tone in humans. Am J Hypertens 2013, 26(6):762-769.

58. Neves C, Tufik S, Chediek F, Poyares D, Cintra F, Roizenblatt M, Abrantes F, Monteiro MA, Roizenblatt S: Effects of sildenafil on autonomic nervous function during sleep in obstructive sleep apnea. Clinics (Sao Paulo) 2010, 65(4):393-400

59. Giachini FR, Lima W, Carneiro FS, Tostes RC, Webb RC: Decreased cGMP level contributes to increased contraction in arteries from hypertensive rats: role of phosphodiesterase 1. Hypertension 2011, 57(3):655-663.

60. Schäfer A, Fraccarollo D, Pförtsch S, Flierl U, Vogt C, PfrAng J, Kobsar A, Renné T, Eigenthaler M, Ertl G, Bauersachs J: Improvement of vascular function by acute and chronic treatment with the PDE-5 inhibitor sildenafil in experimental diabetes mellitus. Brit J Pharmacol 2008, 153(5):886-893.

61. Lee J, Choi KC, Yeum CH, Kim W, Yoo K, Park JW, Yoon PJ: Impairment of endothelium-dependent vasorelaxation in chronic two-kidney, one clip hypertensive rats. Nephrol Dial Transplant 1995, 10(5):619-623.

62. Shimokawa H, Yasutake H, Fujii K, Owada MK, Nakaike R, Fukumoto Y, Takayanagi T, Nagao T, Egashira K, Fujishima M, Takeshita A: The importance of the hyperpolarizing mechanism increases as the vessel size decreases in endothelium-dependent relaxations in rat mesenteric circulation. J Cardiovasc Pharmacol 1996, 28(5):703-711.

63. Wang D, Chabrashvili T, Borrego L, Aslam S, Umans JG: Angiotensin II infusion alters vascular function in mouse resistance vessels: roles of $\mathrm{O}$ and endothelium. J Vasc Res 2006, 43:109-119.

64. Dohi Y, Criscione L, Lüscher TF: Renovascular hypertension impairs formation of endothelium-derived relaxing factors and sensitivity to endothelin-1 in resistance arteries. Br J Pharmacol 1991, 104(2):349-354.

65. Jung O, Schreiber JG, Geiger H, Pedrazzini T, Busse R, Brandes RP: gp91phox-containing NADPH oxidase mediates endothelial dysfunction in renovascular hypertension. Circulation 2004, 109(14):1795-1801.

66. Zou M, Anges C: Cell-cell interaction between platelets and IL-1 beta-stimulated vascular smooth muscle cells in synthesis of thromboxane A2. Prostaglandins Leukot Essent Fatty Acids 1997, 56(2):85-91.

67. Lee KC, Yang YY, Huang YT, Lee FY, Hou MC, Lin HC, Lee SD: Administration of a low dose of sildenafil for 1 week decreases intrahepatic resistance in rats with biliary cirrhosis: the role of NO bioavailability. Clin Sci (Lond) 2010, 119(1):45-55.

68. Lohse MJ, Förstermann U, Schmidt HH: Pharmacology of NO: cGMP signal transduction. Naunyn Schmiedebergs Arch Pharmacol 1998, 358(1):111-112.

doi:10.1186/s12967-014-0250-x

Cite this article as: Dias et al:: Inhibition of phosphodiesterase 5 restores endothelial function in renovascular hypertension. Journal of Translational Medicine 2014 12:250. 